\title{
Airborne Particles in the Urban Environment
}

\author{
Bernard Grobéty ${ }^{1}$, Reto Gieré ${ }^{2}$, Volker Dietze ${ }^{3}$, and Peter Stille ${ }^{4}$
}

articulate matter is an important constituent of our atmosphere and has a critical impact on natural processes and human health. Although they are a minor component of the average global mass flux, anthropogenic particles are abundant in the urban environment, where they contribute substantially to air pollution. Particulate matter is routinely monitored in urban areas, but different particle types can be distinguished only by combining single-particle chemical analysis with bulk analysis of trace elements and measurement of isotope ratios. Such chemical tracers also allow for source identification and thus for targeted mitigation of anthropogenic particle pollution.

KEYWORDs: particulate matter, urban environment, particle monitoring, chemical and isotopic tracers, health effects, air pollution

neodymium, lead) are excellent fingerprints for anthropogenic particle sources and thus allow us to distinguish between natural and man-made PM (Lahd Geagea et al. 2008).

\section{PARTICULATE MATTER IN THE URBAN ENVIRONMENT}

\section{INTRODUCTION}

Airborne particulate matter (PM) — suspended solid particles with diameters between a few nanometers ( $\mathrm{nm}$ ) and several micrometers $(\mu \mathrm{m})$ - has always been a constituent of the Earth's atmosphere. Today, PM has an average concentration in remote locations of 300-400 million particles per cubic meter (Jaenicke 1980). Nucleation from a gaseous or liquid phase and mechanical abrasion of solids are the main physical processes by which PM is formed. Man-made PM accounts for only 2-3\% of the particle mass emitted globally (Gieré and Querol 2010 this issue). The physical and chemical properties of anthropogenic PM, however, are distinct from those of natural PM and have a decisive influence on human health and natural processes (e.g. climate evolution). Urban areas are especially exposed to anthropogenic aerosol particles due to the great abundance of sources. Many studies have shown a positive correlation between PM mass or number concentrations and adverse health effects (Pope and Dockery 2006). The most important task in air pollution control is to prevent contaminants from entering the atmosphere. Mitigation of air pollution hazards requires detailed knowledge of the nature of the particles, their emission sources, transport, and final fate, and their impact on the environment, including human well-being. Specific organic molecules, trace elements (e.g. rare earth elements), and the isotopic composition of certain elements (e.g. strontium,

\footnotetext{
1 Département de Géosciences, Université de Fribourg $\mathrm{CH}-1700$ Pérolles, Fribourg, Switzerland E-mail: bernard.grobety@unifr.ch

2 Institut für Geowissenschaften, Albert-Ludwigs-Universität D-79104 Freiburg, Germany

3 Research Center for Human Biometeorology, Air Quality Department, Deutscher Wetterdienst, D-79104 Freiburg, Germany

4 LHyGeS-UMR7517, EOST, Université de Strasbourg, INSU/CNRS 1 rue Blessig, F-67084 Strasbourg, France
}

Suspended solid particles and volatile organic compounds (VOCs) are the main constituents of the urban air pollution commonly called smog. In cities like Kathmandu, New Delhi, and Cairo, peak concentrations of $300 \mu \mathrm{g} / \mathrm{m}^{3}$ for particles smaller than $10 \mu \mathrm{m}\left(\mathrm{PM}_{10}\right)$ are often reached or surpassed. On bad days, inhabitants of these cities inhale several hundred million particles with each breath! Daily $\mathrm{PM}_{10}$ averages are consistently several times higher than the targets set in the air quality guidelines of the World Health Organization, that is, an annual mean of $20 \mu \mathrm{g} / \mathrm{m}^{3}$ and a maximum concentration over a period of 24 hours of $50 \mu \mathrm{g} / \mathrm{m}^{3}$. These are the lowest levels at which mortality has been shown to increase, with more than 95\% confidence, in response to long-term exposure. The cities mentioned above are not alone; particle concentrations exceeding health safety levels are the rule rather than the exception in most large cities of the world (TABLE 1). The main contributors to the particle load are human activities in and around the cities, but the situation may be exacerbated by the presence of natural particles, such as mineral dust, sea spray, and biogenic material. Anthropogenic particles are generated through combustion of fossil fuels and biofuels, industrial activities, abrasion, and the resuspension of natural particles by traffic, construction, and agricultural activities (FIG. 1).

\section{Combustion-Derived Particles: \\ Soot, Sulfates, Nitrates, Ammonia}

The term soot refers to a primary combustion-derived particle type, which has a characteristic and well-defined structure (see Glossary in Gieré and Querol 2010 this issue). During combustion, hydrocarbon molecules decompose into various fragments, such as aromatic structures, acetylene, alkanes, alkanoic acids, aromatic aldehydes, polycyclic aromatic hydrocarbons (PAHs), and graphene-like compounds (Richter and Howard 2000). PAHs are of special concern because of their carcinogenic and mutagenic properties. During cooling and dilution, these primary species may condense to liquid or solid spherical particles (soot) with diameters of $30-50 \mathrm{~nm}$. Subsequently, they aggregate into larger chains (FIG. 2A) and may grow by adsorption of 


\begin{tabular}{|c|c|c|c|}
\hline City & $\mathrm{PM}_{10}$ & City & \\
\hline Beijing & 105 & I & 26 \\
\hline Berlin & 49 & Los Angeles & 44 \\
\hline Cairo & 150 & Mexico City & 53 \\
\hline Cape Town & 29 & New York & 22 \\
\hline New Delhi & 171 & Prague & 66 \\
\hline Dhaka & 120 & Rome & 58 \\
\hline Hanoi & 38 & São Paulo & 41 \\
\hline Karachi & 227 & Stockholm & 16 \\
\hline Kathmandu & 127 & Sydney & 21 \\
\hline Lima & 118 & Tokyo & 33 \\
\hline
\end{tabular}

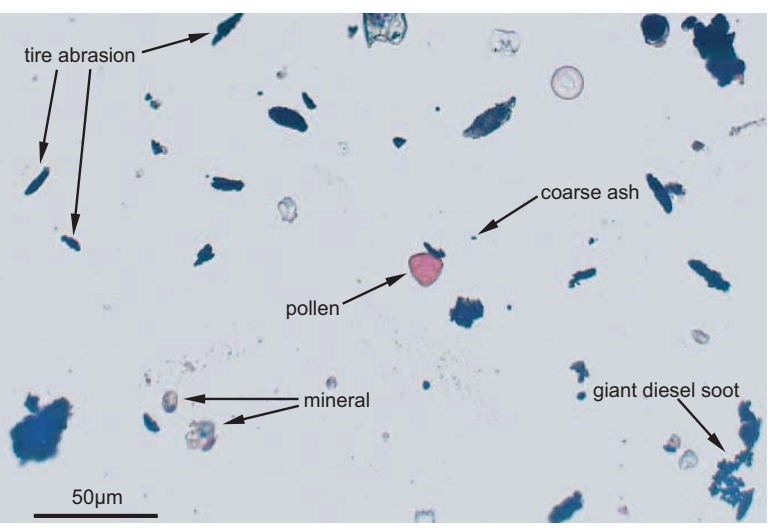

FigurE 1 Transmitted-light microscope image of airborne partiFiguRE 1 cles collected over a period of 7 days with a passive sampler (Sigma-2 type) at a roadside location in Mainz, Germany. Рното ву V. Dietze

other species with low vapor pressures. Soot particles contain characteristic organic species related to their sources (e.g. benzoquinone, phenolic groups), but these fingerprints may be rapidly blurred by ageing processes, such as those due to reaction with ozone (Vernooij et al. 2009).

Electricity generation, traffic, oil- and wood-fired heating, and industrial manufacturing processes are the main anthropogenic sources of soot. In urban areas, soot typically accounts for $25-50 \%$ of the total mass of ambient $\mathrm{PM}_{2.5}$, i.e. particles with diameters less than $2.5 \mu \mathrm{m}$ (www epa.gov/air/emissions). Soot emission from fossil fuel combustion for heating and transportation purposes has been reduced substantially in the past ten years due to the introduction of particle filters. This reduction, however, has been negated in many places by the increase in sources due to increased traffic density and industrial development, especially in emerging countries.

The sulfur and nitrogen contents of fossil fuels are converted to sulfur dioxide $\left(\mathrm{SO}_{2}\right)$ and nitrous oxides $\left(\mathrm{NO}_{\mathrm{x}}\right)$ during combustion. Oxidation of these species by reaction with $\mathrm{OH}$ radicals (during the day) and ozone (at night) in the atmosphere leads to the formation of sulfuric and nitric acids as well as peroxyacetyl nitrates (PANs). These
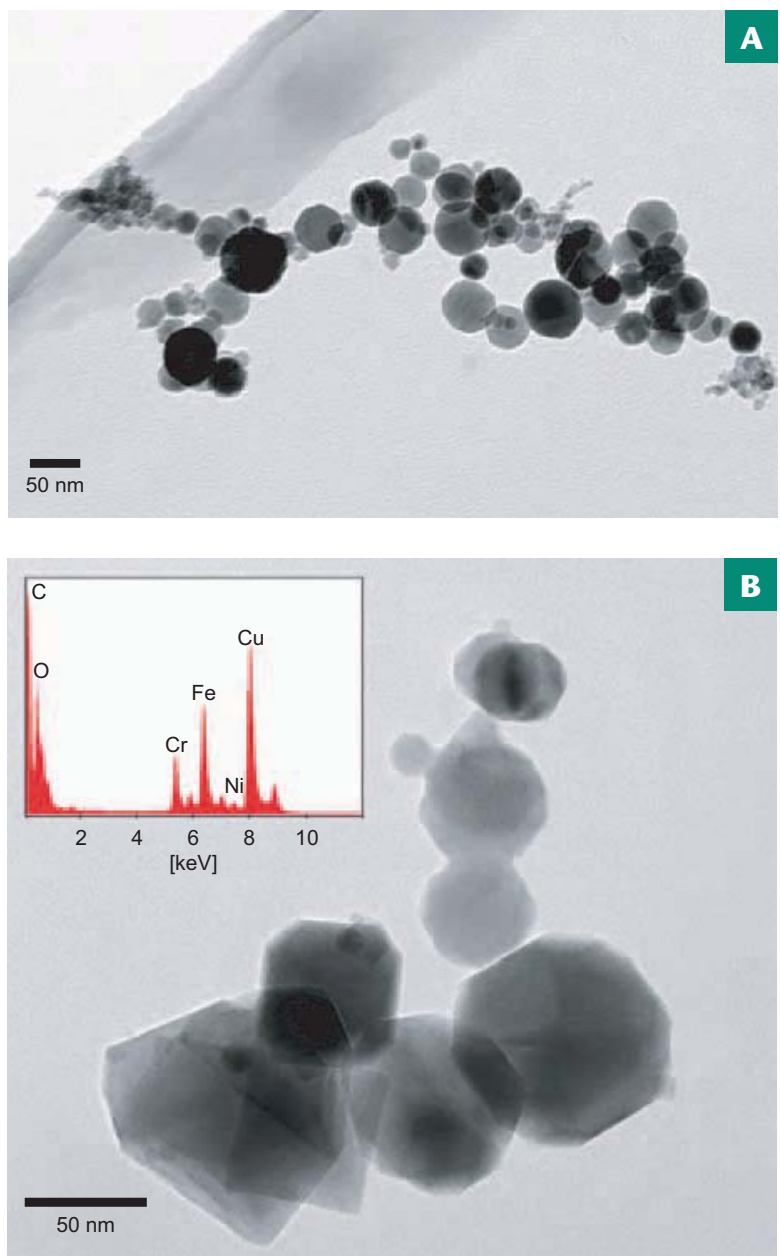

FIgURE 2

Anthropogenic aerosol particles. (A) Soot collected from the exhaust of a diesel car engine. (B) Brightfield transmission electron microscope (TEM) image of ( $\mathrm{Fe}, \mathrm{Cr}, \mathrm{Ni}$ )spinel particles emitted during soldering of steel components. Inset: Energy-dispersive X-ray spectrum of a particle. The copper $(\mathrm{Cu})$ and carbon $(C)$ peaks are from the TEM grid and the substrate, respectively. Рнотоs by B. Grobéty

compounds have low volatility and may be incorporated into water droplets (causing fog), adsorbed onto primary particles (e.g. soot), or form particles on their own by homogeneous nucleation. Nitrate, nitric acid, and sulfuric acid may react with their substrates or other adsorbed species to form compounds such as sodium nitrate $\left(\mathrm{NaNO}_{3}\right.$, on sea-salt particles), ammonium nitrate $\left(\mathrm{NH}_{4} \mathrm{NO}_{3}\right)$, and ammonium sulfate $\left[\left(\mathrm{NH}_{4}\right)_{2} \mathrm{SO}_{4}\right]$, all of which are very common in airborne PM (Vester et al. 2007). Oxidation of primary volatile organic species may also produce lowvolatility compounds, which subsequently condense on the surfaces of primary particles. These secondary organic aerosol (SOA) species may comprise the majority of carbonaceous PM mass, not only in rural and remote areas but also in urban settings (Engling and Gelencsér 2010 this issue).

Coal combustion facilities are a major source of fine PM $\left(\mathrm{PM}_{2.5}\right)$ in the atmosphere, even though air pollution control devices typically remove more than $99 \%$ of the PM from flue gases. The particle-capture efficiency of these devices, however, is size dependent. For example, the efficiency of electrostatic precipitators is lower for fine PM than for coarse PM $(>2.5 \mu \mathrm{m})$. Fine particles are therefore emitted preferentially and, at the same time, they exhibit the longest atmospheric residence times. Only a few studies have been published on PM emissions from coal-fired 
power plants, even though such power stations account for $42 \%$ of worldwide electricity production (2006 data; see www.eia.doe.gov/iea). Many of these plants combust a blend of coal and other fuels (scrap tires, wood, waste), and emissions vary accordingly. In addition to phases typical of coal fly ash (aluminum-silicate glass, magnetite, hematite), the emitted PM may include soot, amorphous selenium, lime, and various types of crystalline metal sulfates, such as anglesite, anhydrite, and barite (Jablonska et al. 2001; Gieré et al. 2006). These sulfates are distinct from the "sulfate" aerosols commonly reported in the atmospheric science literature (e.g. sulfuric acid droplets, ammonium sulfate).

\section{Particles Originating from Traffic and Industrial Activities}

Tire abrasion contributes significantly to atmospheric PM in urban areas, especially to the $\geq 10 \mu \mathrm{m}$ size fraction and near roads. Tires contain a multitude of chemical compounds, including rubber (an elastic hydrocarbon polymer derived from latex or produced synthetically), agents required in the vulcanization process (e.g. zinc oxide, sulfur), and reinforcing fillers, textiles, and wires (e.g. carbon, silica, nylon, steel). The amounts of these materials vary widely among manufacturers and types of tires, which complicates any composition-based quantitative assessment of the tire-derived particles in ambient air samples. However, tire-abrasion particles exhibit distinct irregular shapes, which can be recognized easily with the aid of a transmitted-light microscope (FIG. 1).

Railway traffic is another prominent source of PM, especially metallic particles. In subway stations, the $\mathrm{PM}_{2.5}$ concentration may reach $60 \mu \mathrm{g} / \mathrm{m}^{3}$, as measured, for example, in the Helsinki subway system (Aarnio et al. 2005). In underground stations, almost half of the emissions consist of iron and iron oxide particles, which are formed by friction between break pads and wheels and are resuspended by the draft of passing trains.

Industrial processes account for $\sim 35 \%$ of the PM mass emitted globally through human activities. Ferrous and nonferrous metal foundries emit carbonaceous particles, including soot, and various metal oxides, the nature of which depends on the processes used and materials produced. Smelters typically emit particles consisting of a complex array of phases. Lead (Pb) smelters, for example, generate various types of $\mathrm{Pb}$ sulfates, metallic $\mathrm{Pb}, \mathrm{Pb}$ sulfides, and $\mathrm{Pb}$ chlorides (Batonneau et al. 2004). In addition to their potentially severe health impacts, these particles can cause significant contamination of soils and waters in adjacent areas (Ettler et al. 2004).

Ultrafine particles $(<0.1 \mu \mathrm{m})$ can be emitted during material-processing activities, such as polishing and soldering of metals. Bursts of more than one million iron-nickel oxide particles per cubic centimeter, with maxima in the grain-size distribution at $40 \mathrm{~nm}$ and $150 \mathrm{~nm}$, have been observed in the vicinity of automated soldering stations (B. Grobéty, unpublished data; FIG. 2B).

\section{Particles Originating from Other Human Activities}

PM in urban environments also comprises dust from agricultural activities and includes silicates, carbonates, phosphates and nitrates (from fertilizers), and organic material. Construction and demolition processes produce abundant, mostly coarse-mode particles derived from the primary building materials, i.e. sand, cement, glass, bricks, gypsum, carbonates, and, in some cases, asbestos fibers (Kaegi 2004). A prominent example is the dust produced through the collapse of the World Trade Center on September 11, 2001. In addition to inorganic particles, this dust also contained PAHs, polychlorinated biphenyls (PCBs), furans, and dioxins. This type of dust becomes airborne not only during construction and demolition activities but also later, as a result of resuspension by traffic.

\section{Nanotechnology and Particle Emission}

Since the development in the early 1990s of carbon fullerenes and nanotubes (CNTs) with their special physical properties, ultrafine particles and fibers have been at the forefront of technology. Both the numbers of applications and the amounts of engineered nanoparticles are increasing steadily; hence, the manufacture and use of nanomaterials provide potential PM emission sources (Buseck and Adachi 2008). Release experiments with CNTs (Maynard et al. 2004) and exposure modeling for CNTs and nanoparticles of $\mathrm{TiO}_{2}$ and silver (Mueller and Nowack 2008) have shown that engineered nanoparticles are detectable not only at the production sites but also in the environment. The predicted concentrations, however, are much higher in water bodies than in the atmosphere.

\section{MONITORING AND SAMPLING OF URBAN AEROSOL PARTICLES}

Monitoring networks are essential for measuring and distinguishing PM in urban areas. Various standardized sampling and analysis methods are in use around the world. Conventional active samplers, which draw in air with the aid of a pump, are designed for particles with aerodynamic equivalent diameters of $<10 \mu \mathrm{m}$. They are equipped with an impactor, which is a device that separates particles aerodynamically according to a respective diameter threshold. The mass concentration of PM is determined either periodically (24-hour mean) or continuously.

Coarse PM (>2.5 $\mu \mathrm{m})$ can also be collected with passive samplers [e.g. Leith-Wagner (Ott et al. 2008) or Sigma-2 devices], which are based on the sedimentation principle (Stokes' law). The Sigma-2 sampler, for example, collects particles in the 2.5-100 $\mu \mathrm{m}$ size range and is used for routine air-quality measurements, monitoring of particle concentrations in time intervals of days to weeks (Norra et al. 2007), and collection of samples for subsequent chemical and isotopic analyses. Automated light and electron optical analyses of the sampling substrates provide morphological and chemical information on a singleparticle basis, an important advantage over bulk analytical methods (Schleicher et al. 2010). In combination with densitometric parameters, the automated analysis of optical images, such as that shown in Figure 1, provides mass concentrations and size distributions for both transparent (mostly natural) and opaque (mostly anthropogenic) particles, and for the sum of the two fractions (total coarse particles). Figure 3 shows the mass concentration of undifferentiated coarse particles at roadside locations in Cairo, Hanoi, and Berlin. Even though the three locations differ substantially in terms of absolute mass concentrations, the size distributions are similar, with a maximum at $10-20 \mu \mathrm{m}$. Such patterns are characteristic for roadside locations, reflecting the main particle sources (road and tire abrasion, resuspension).

Particle-counting devices and chemical analysis tools, which are used for research purposes that go beyond daily public monitoring of PM, have been described in a previous Elements article (Buseck and Adachi 2008). 


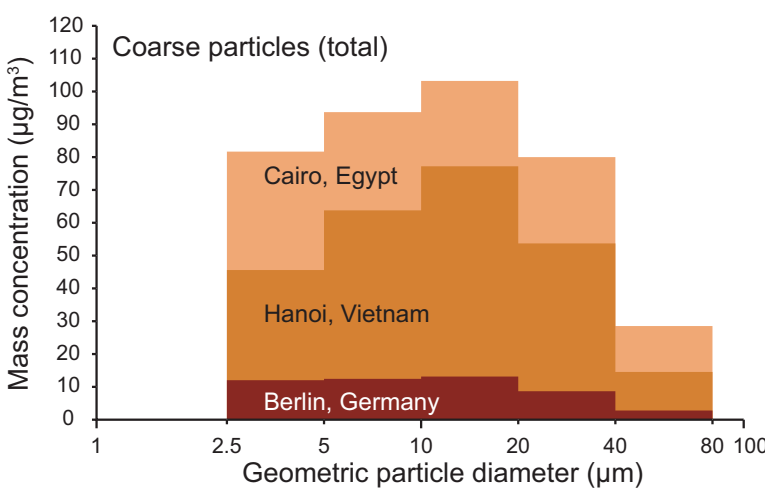

FigurE 3 Average mass concentrations of airborne particles collected with a passive sampler (Sigma-2 type) at roadside locations in Cairo, Hanoi, and Berlin. Monitoring periods: Cairo, November 2007 to April 2008; Hanoi, November 2008 to April 2009; Berlin, June 2003 to June 2004. Unpublished data

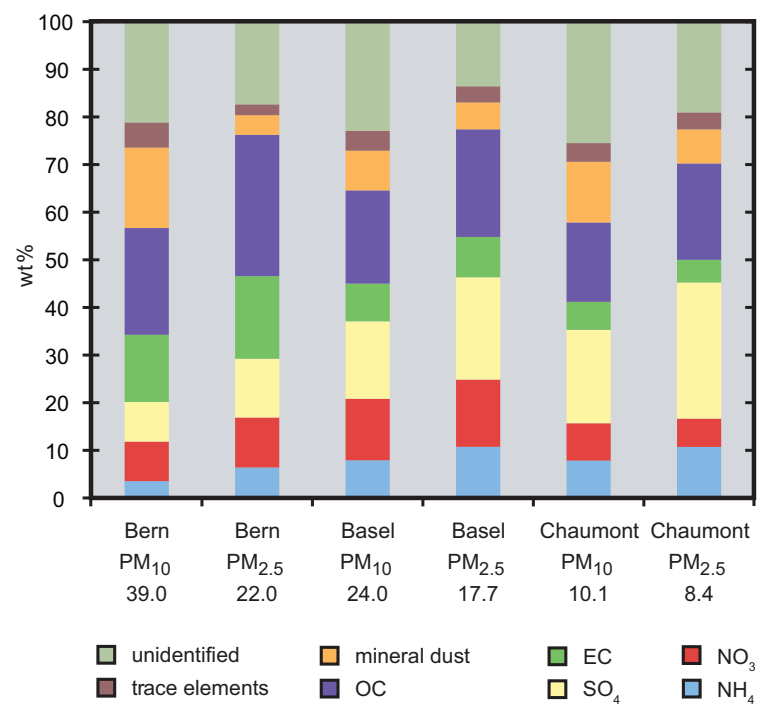

Fverage compositions (wt\%) of airborne particles 4 from different locations in Switzerland: Bern (citycenter curbside); Basel (suburban residential area); Chaumont (rural area more than $1000 \mathrm{~m}$ above sea level). The data shown were obtained from $120 \mathrm{PM}_{10}$ and $82 \mathrm{PM}_{2.5}$ samples collected during a 14-month period. EC: elemental, refractory carbonaceous material; OC: organic carbonaceous material (may contain a considerable fraction of biogenic carbon). The unidentified component is mainly water and biogenic material. Total average concentrations $\left(\mu \mathrm{g} / \mathrm{m}^{3}\right)$ are indicated below each location name (after Hueglin et al. 2005).

\section{MASS CONCENTRATION, COMPOSITION, AND SIZE DISTRIBUTION OF URBAN PARTICULATE MATTER}

The composition of urban PM depends strongly on the geographical location, meteorological conditions during sampling, and size fraction of the aerosol particles considered (FIgs. 3, 4). Urban PM is characterized by volume and mass concentrations that are generally one order of magnitude higher than those in rural or remote background areas (FIG. 5).

In the urban environment, it is important to distinguish between "hot spot" sampling locations close to major roads and background locations situated in residential areas. Regardless of sampling site, the bulk composition is generally dominated by combustion products, that is, particles containing sulfate + nitrate + ammonia (SNA), and primary and secondary carbonaceous species including soot. Carbonaceous particles amount to $50-70 \mathrm{wt} \%$ of the bulk

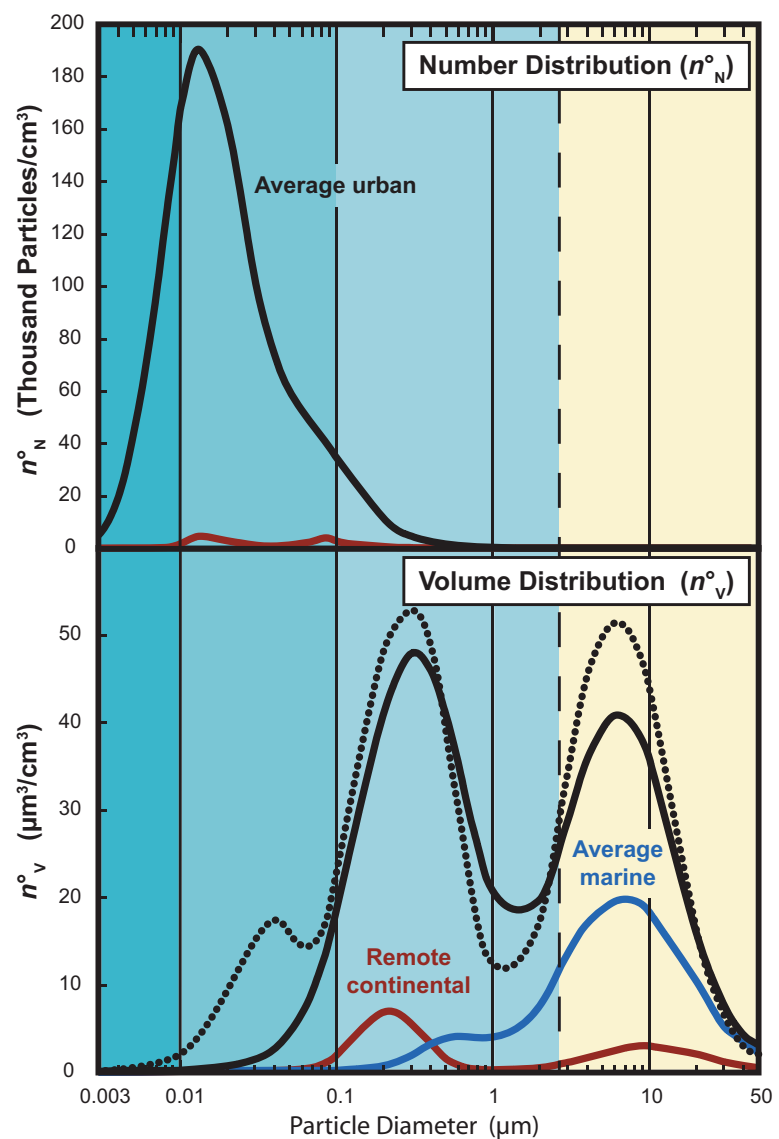

Figure 5 Typical number distribution (number of particles per Figure 5 unit volume, $n^{0} \mathrm{~N}$ ) and volume distribution (volume of particles per unit volume, $n^{0} \mathrm{v}$ ) for average urban (black line), remote continental (brown line), and average marine (blue line) aerosol particles. Average marine aerosol particles show extremely low $n^{0} \mathrm{~N}$ values and thus do not appear in the upper diagram. The black dotted curve shows $n^{0}$ v for an urban air sample measured next to a freeway; traffic leads to higher $n^{0} v$ values for both fine particles $(<2.5 \mu \mathrm{m}$, derived primarily from combustion processes) and coarse particles $(>2.5 \mu \mathrm{m}$, derived from abrasion of tires, brake pads, and pavement, and from resuspension of dust).

Compiled from Seinfeld and Pandis (2006)

composition, and a considerable fraction of these may be of biogenic origin (e.g. spores and pollen; Bauer et al. 2008). The mineral dust contribution to the coarse fraction along roads is high due to resuspension of particles deposited previously. The SNA fraction increases downwind and away from roads due to particle "ageing," that is, continuous modification via chemical reactions and mixing in the atmosphere.

Episodic dust storms and volcanic eruptions may lead to deposition of mineral matter thousands of kilometers away from their source regions. Such storms and volcanic ash clouds may hit populated areas along their trajectory (FIG. 6) and significantly alter the composition and size distribution of urban PM. They also cause a dramatic reduction of visibility and thus pose a considerable hazard to air, ship, road, and train traffic, especially in urban environments. Impressive examples of these effects are provided by the recent dust storms in Sydney, Australia (see cover image), when $\mathrm{PM}_{10}$ concentrations peaked at $1700 \mu \mathrm{g} / \mathrm{m}^{3}$ (24-hour mean), and by the havoc in the European airtransport system following the volcanic eruption at Eyjafjallajökull on Iceland in April 2010. 


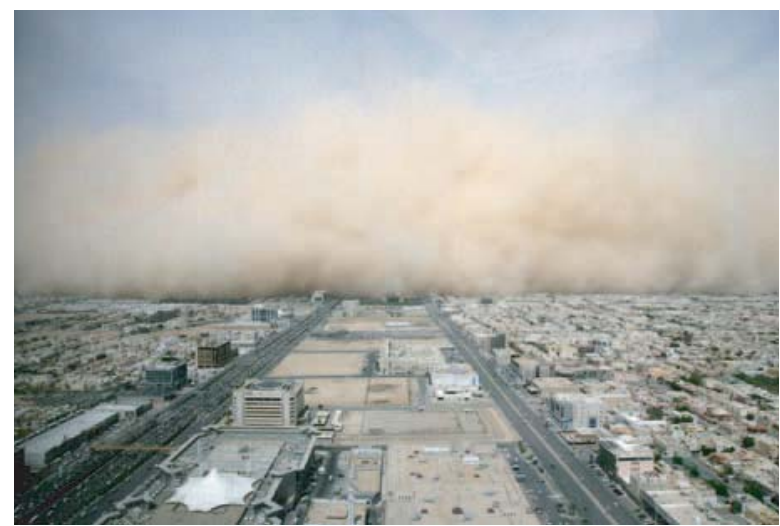

Figure 6

Dust cloud enveloping Riyadh, Saudi Arabia (March 10, 2009). AFP/GetTy IMAGES

\section{IDENTIFICATION OF ANTHROPOGENIC PARTICLE SOURCES}

The chemical and isotopic compositions of particles can provide unique fingerprints pointing to their sources, thus enabling PM tracing in the environment. For example, Ault et al. (1970) demonstrated in their pioneering work that the ${ }^{206} \mathrm{~Pb} /{ }^{204} \mathrm{~Pb}$ values of atmospheric PM vary significantly both within a city and among cities, which makes it possible to identify point sources of $\mathrm{Pb}$. Industrial $\mathrm{Pb}$ is derived mostly from orebodies, whose $\mathrm{Pb}$ isotope compositions differ markedly from that of average crustal rocks. Ancient orebodies, like those formed in Australia during the Precambrian (which provided most of the $\mathrm{Pb}$ used as an antiknocking agent in leaded gasoline), have lower $\mathrm{Pb}$ isotope ratios $\left({ }^{206} \mathrm{~Pb} /{ }^{207} \mathrm{~Pb}=1.042\right)$ than average Phanerozoic crustal rocks (1.18-1.2; labeled as "natural" Pb in Figure 7A) (Monna et al. 1997). Isotope-ratio diagrams permit the evaluation of compositional relationships between airborne particles and various point sources. For example, in the Strasbourg area (France), the lowest $\mathrm{Pb}$ isotope ratios were found in soot from car exhausts (FIg. 7A) whereas higher values were exhibited by industrial filter dusts collected from a nearby thermal power plant, a steel plant, and domestic and chemical waste incinerators (Lahd Geagea et al. 2008). Similar values have been found for other waste incinerators in France (Carignan et al. 2005).

Combining isotope ratios of strontium and neodymium $\left({ }^{87} \mathrm{Sr} /{ }^{86} \mathrm{Sr},{ }^{143} \mathrm{Nd} /{ }^{144} \mathrm{Nd}\right)$ as environmental tracers with the $\mathrm{Pb}$ isotope system allows for much better discrimination between different anthropogenic emissions (FIG. 7B). This combined approach is important because $\mathrm{Pb}$ isotope ratios alone might not allow distinction between different sources.

Stable isotopes, such as the isotopes of carbon, nitrogen, and sulfur (S), have also been used successfully to deduce the origin of PM in urban settings. For example, singleparticle $\mathrm{S}$ isotope compositions $\left({ }^{32} \mathrm{~S},{ }^{34} \mathrm{~S}\right)$ determined using secondary ion mass spectrometry may allow not only the identification of the $S$ source but also the elucidation of the oxidation pathways (homogeneous versus heterogeneous) on the basis of the isotope fractionation behavior (Sinha et al. 2008).

The distribution of the rare earth elements, the use of which has increased exponentially during the last fifty years, is also well suited to tracing the origin of certain particles (Lahd Geagea et al. 2008). The presence of other trace and minor elements may also be diagnostic of a specific source. Particles consisting of a combination of copper, antimony, and tin, for example, indicate a source arising from abrasion of vehicle brake pads (Sternbeck et
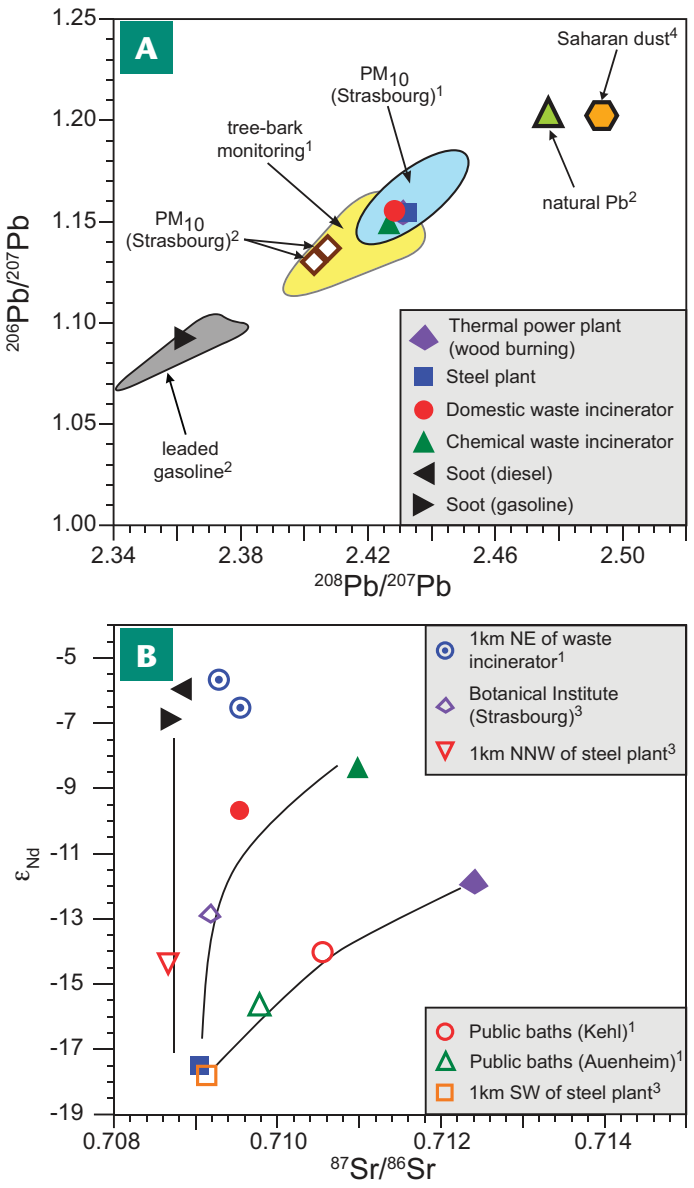

FIguRE 7

Isotope data for samples of airborne particles and particle sources collected in the urban area of

Strasbourg (France) and Kehl (Germany). (A) Three-isotope lead $\mathrm{Pb})$ diagram showing the principal natural and anthropogenic sources (filled symbols). Present-day $\mathrm{PM}_{10}$ (light blue field; samples collected in 2005-2006) has a $\mathrm{Pb}$ isotope composition very similar to the compositions of emissions from the local anthropogenic sources. Older $\mathrm{PM}_{10}$ (open brown diamonds; samples collected in 1995 , i.e. before leaded gasoline was phased out) has significantly lower $\mathrm{Pb}$ isotope ratios, emphasizing the impact of leaded gasoline at that time. The yellow field defines the range of $\mathrm{Pb}$ isotope

compositions obtained from tree bark sampled in urban and remote locations around Strasbourg and Kehl, covering a 10-year history of $\mathrm{Pb}$ emissions. (B) ${ }^{87} \mathrm{Sr} /{ }^{86} \mathrm{Sr}-{ }^{143} \mathrm{Nd} /{ }^{144} \mathrm{Nd}$ diagram, showing clearly that the different anthropogenic sources (filled symbols) are distinct in their $\mathrm{Sr}$ and $\mathrm{Nd}$ isotope compositions, thus allowing the origin of the PM (open symbols) to be identified using isotope-mixing lines (shown in black). ${ }^{143} \mathrm{Nd} /{ }^{144} \mathrm{Nd}$ ratios are expressed as $\varepsilon \mathrm{Nd}=$ $\left(\left[{ }^{143} \mathrm{Nd} /{ }^{144} \mathrm{Nd} / 0.51264\right]-1\right) \times 10^{4}$. Data from: 1 Lahd GeAGEA et al. (2008); 2 Monna et al. (1997); 3 P. Stille, unpublished data; 4 Grousset AND BISCAYE (2005)

al. 2002). Therefore, minor and trace elements should be included in studies aimed at source apportionment, especially in urban areas (Pacyna 1998).

\section{HEALTH EFFECTS}

Adverse health effects due to frequent exposure to elevated PM concentrations are undisputed (Pope and Dockery 2006) and have been documented in many epidemiological studies. However, the particle properties responsible for the toxicity are not well understood. An open issue is whether particle toxicity resides in some specific fraction of the particles, as defined by their chemical composition, shape, or size (Harrison and Yin 2000). Reactive oxygen species (ROS), believed to play a major role in the toxicity of particles, may be related to PM surface properties, the presence of transition metals, intracellular iron mobilization, or lipid peroxidation. Persistent ROS formation leads 
to lung inflammation and cardiovascular diseases (Schins 2002). Nanoparticles are also a concern because they are able to penetrate cells and cause damage to DNA.

\section{CONCLUDING REMARKS}

In the last decades, tremendous advances have been made in the characterization and source determination of particles found in the urban atmosphere, as well as in the reduction of particle emissions. However, far more data on the physical and chemical properties of individual particles are required for a more statistically relevant differentiation among various particle types. Moreover, future research should focus on a better understanding of the consequences these particles have for the environment and our well-being.

\section{ACKNOWLEDGMENTS}

We thank Mihály Pósfai, Peter Buseck, Martin Ebert, Ella Goldenberg, Guenter Engling, and David Vaughan for their constructive reviews, and Thomas Jauss for drawing the diagrams. -

\section{REFERENCES}

Aarnio P, Yli-Tuomi T, Kousa A, Mäkelä T, Hirsikko A, Hämeri K, Räisänen M, Hillamo R, Koskentalo T, Jantunen M (2005) The concentrations and composition of and exposure to fine particles $\left(\mathrm{PM}_{2.5}\right)$ in the Helsinki subway system. Atmospheric Environment 39: 5059-5066

Ault WU, Senechal RG, Erlebach WE (1970) Isotopic composition as a natural tracer of lead in the environment. Environmental Science \&Technology 4: 305-313

Batonneau Y, Bremard C, Gengembre L, Laureyns J, Le Maguer A, Le Maguer D, Perdrix E, Sobanska S (2004) Speciation of $\mathrm{PM}_{10}$ sources of airborne nonferrous metals within the $3-\mathrm{km}$ zone of lead/ zinc smelters. Environmental Science \& Technology 38: 5281-5289

Bauer H, Schueller E, Weinke G, Berger A, Hitzenberger R, Marr IL, Puxbaum H (2008) Significant contributions of fungal spores to the organic carbon and to the aerosol mass balance of the urban atmospheric aerosol. Atmospheric Environment 42: 5542-5549

Buseck PR, Adachi K (2008) Nanoparticles in the atmosphere. Elements 4: 389-394

Carignan J, Libourel G, Cloquet C, Le Forestier L (2005) Lead isotopic composition of fly ash and flue gas residues from municipal solid waste combustors in France: Implications for atmospheric lead source tracing. Environmental Science \& Technology 39: 2018-2024

Engling G, Gelencsér A (2010) Atmospheric brown clouds: From local air pollution to climate change. Elements 6: 223-228

Ettler V, Mihaljevic M, Komarek M (2004) ICP-MS measurements of lead isotopic ratios in soils heavily contaminated by lead smelting: tracing the sources of pollution. Analytical \& Bioanalytical Chemistry 378: 311-317

Gieré R, Querol X (2010) Solid particulate matter in the atmosphere. Elements 6 : 215-222

Gieré R, Blackford MG, Smith KL (2006) TEM study of $\mathrm{PM}_{2.5}$ emitted from coal and tire combustion in a thermal power station. Environmental Science \& Technology 40: 6235-6240

Grousset FE, Biscaye PE (2005) Tracing dust sources and transport patterns using $\mathrm{Sr}, \mathrm{Nd}$ and $\mathrm{Pb}$ isotopes. Chemical Geology 222: 149-167
Harrison RM, Yin JX (2000) Particulate matter in the atmosphere: which particle properties are important for its effects on health? Science of the Total Environment 249: 85-101

Hueglin C, Gehrig R, Baltensperger U, Gysel M, Monn C, Vonmont H (2005) Chemical characterisation of PM2.5, PM10 and coarse particles at urban, near-city and rural sites in Switzerland. Atmospheric Environment 39: 637-657

Jablonska M, Rietmeijer FJM, Janeczek J (2001) Fine-grained barite in coal fly ash from the Upper Silesian industrial region. Environmental Geology 40: 941-948

Jaenicke R (1980) Natural aerosols. Annals of the New York Academy of Science 338: 317-329

Kaegi R (2004) Chemical and morphological analysis of airborne particles at a tunnel construction site. Journal of Aerosol Science 35: 621-632

Lahd Geagea M, Stille P, Gauthier-Lafaye F, Millet M (2008) Tracing of industrial aerosol sources in an urban environment using $\mathrm{Pb}, \mathrm{Sr}$, and $\mathrm{Nd}$ isotopes. Environmental Science \& Technology 42: 692-698

Maynard AD, Baron PA, Foley M, Shvedova AA, Kisin ER, Castranova V (2004) Exposure to carbon nanotube material: Aerosol release during the handling of unrefined single-walled carbon nanotube material. Journal of Toxicology and Environmental Health A 67: $87-107$

Monna F, Lancelot J, Croudace IW, Cundy AB, Lewis JT (1997) Pb isotopic composition of airborne particulate material from France and the southern United Kingdom: Implications for $\mathrm{Pb}$ pollution sources in urban areas. Environmental Science \& Technology 31: 2277-2286

Mueller NC, Nowack B (2008) Exposure modeling of engineered nanoparticles in the environment. Environmental Science \& Technology 42: 4447-4453

Norra S, Hundt B, Stüben D, Cen K, Liu C, Dietze V, Schultz E (2007) Size, morphological and chemical characterization of aerosols polluting the Beijing atmosphere in January/February 2005. In: Morrison GM, Rauch S (eds) Highway and Urban Environment. Proceedings of the $8^{\text {th }}$ Highway and Urban Environment Symposium, Springer, Berlin, pp 167-180

Ott DK, Cyrs W, Peters TM (2008) Passive measurement of coarse particulate matter, $\mathrm{PM}_{10-2.5}$. Journal of Aerosol Science 39: 156-167
Pacyna JM (1998) Source inventories for atmospheric trace metals. Atmospheric particles. In: Harrison RM, Van Grieken RE (eds) IUPAC Series on Analytical and Physical Chemistry of Environmental systems, volume 5, pp 387-423

Pope CA, Dockery DW (2006) Health effects of fine particulate air pollution: Lines that connect. Journal of the Air and Waste Management Association 56: 709-742

Richter H, Howard JB (2000) Formation of polycyclic aromatic hydrocarbons and their growth to soot-a review of chemical reaction pathways. Progress in Energy and Combustion Science 26: 565-608

Schins RPF (2002) Mechanisms of genotoxicity of particles and fibers. Inhalation Toxicology 14: 57-78

Schleicher N, Kramar U, Norra S, Dietze V, Kaminski U, Cen K, Yu K (2010) $\mu$-scale variations of elemental composition in individual atmospheric particles by means of synchrotron radiation based $\mu$-XRF analysis. 20th International Congress on X-ray optics and microanalysis, AIP Conference Proceedings 1221: 172-180

Seinfeld JH, Pandis SN (2006) Atmospheric Chemistry and Physics: From Air Pollution to Climate Change. John Wiley, New York, 1203 pp

Sinha BW, Hoppe P, Huth J, Foley S, Andreae MO (2008) Sulfur isotope analyses of individual aerosol particles in the urban aerosol at a central European site (Mainz, Germany). Atmospheric Chemistry and Physics 8: 7217-7238

Sternbeck J, Sjödin A, Andréasson K (2002) Metal emissions from road traffic and the influence of resuspensionresults from two tunnel studies. Atmospheric Environment 36: $4735-4744$

Vernooij MGC, Mohr M, Tzvetkov G, Zelenay V, Huthwelker T, Kaegi R, Gehrig R, Grobéty B (2009) On source identification and alteration of single diesel and wood smoke soot particles in the atmosphere; an X-ray microspectroscopy study. Environmental Science \& Technology 43: 5339-5344

Vester BP, Ebert M, Barnert EB, Schneider J, Kandler K, Schütz L, Weinbruch S (2007) Composition and mixing state of the urban background aerosol in the Rhein-Main area (Germany). Atmospheric Environment 41: 61026115 